\title{
Comment to the Manifesto
}

\author{
Judith Simon
}

In Sect. 2.1., the manifesto rightly emphasizes the linkages between knowledge, power and control-a relationship that has occupied philosophers from Bacon all the way to Michel Foucault. Historically, churches and later on, states have long been the major informational agents, collecting data about their members and citizens from the date of birth until their deaths. Naturally, this information gathering has never stopped at national boundaries, since knowledge about the enemies has been just as essential as a means of staying in control.

Nowadays, as the Manifesto correctly notes, new informational agents, new powerful players have emerged on the knowledge/power axes: big internet companies, such as Facebook, Google or Amazon, as much as the more hidden ones controlling the backbone of the internet traffic. These actors occupy enormously powerful nodes, and function as "obligatory passage points" (Callon 1986) in epistemic, just as much as in economic and political matters.

The Manifesto seems to suggest that we have entered a post-Westphalian world in which nation states seem to have lost much of their power. On the surface this observation appears almost commonsensical: not only require many challenges we face multi-national effort - think of the Kyoto protocol as an attempt to tackle climate change. We also have various transnational authorities that pose restrictions on the sovereignty of nation states.

Nonetheless, recent disclosures around Prism, Tempora and XKeystore, i.e. the exposure of massive surveillance through the American and British Secret Services appears to question this power decline of the nation state. One may say that the states fight their final battles. However, it seems much more plausible to recognize that the old and the new big players on the power/knowledge axis form alliances and work nicely together. It is as it has always been: the powerful constantly enroll allies to increase their power: what has been pursued through marriages in the times

\footnotetext{
J. Simon $(\square)$

Institute of Philosophy, University of Vienna, Vienna, Austria

e-mail: judith.simon@univie.ac.at

IT University Copenhagen, Technologies in Practice Group,

Copenhagen, Denmark

L. Floridi (ed.), The Onlife Manifesto,

DOI 10.1007/978-3-319-04093-6_9, (C) The Author(s) 2015
} 
of kingdoms now simply has a new face: official contracts and hidden agreements between nation states and multi-national internet companies are used to consolidate the supremacy of those mastering the power game.

Blaming the powerful agents alone however, merely requesting new laws and regulations will fall short of offering a remedy to these power games. Instead, we need to understand power as a network effect, power as a result and a cause of distributed agency - and therefore accept partial responsibility for the state of affairs ourselves. As Evgeny Morozov has aptly put it, we-each and every one of us - also need to confront the temptations of information consumerism. As long as we willingly trade our data for free or cheaper products, regulations will not solve the problems: we collude in the game ourselves. Morozov (2013) writes: "European politicians can try imposing whatever laws they want but as long as the consumerist spirit runs supreme and people have no clear ethical explanation as to why they shouldn't benefit from trading off their data, the problem would persist."

In our hyperconnected world, the alliances between the powerful critically depend upon the compliance of the masses. However, it has also never been easier to quit playing along, to change the game through distributed collective action. In principle, we have access to a wide variety of products and services and we can and should be more careful in our choices. We need to understand the relationship between buying and being sold and act accordingly. As consumers, we need to acknowledge that once we stop being willing to pay for products and services, we are paying simply with a different currency - our data. We need to act as citizens as well. We need to mobilize our politicians to stand up to our defense, to counter the on-going attacks to our privacy and to fulfill their responsibilities as our representatives in drafting and enforcing laws and regulations to secure our freedom.

Open Access This chapter is distributed under the terms of the Creative Commons Attribution Noncommercial License, which permits any noncommercial use, distribution, and reproduction in any medium, provided the original author(s) and source are credited.

\section{References}

Callon, M. 1986. Some elements of a sociology of translation: Domestication of the scallops and the fishermen of St Brieuc Bay. In Power, action and belief: A new sociology of knowledge, ed. J. Law, 196-233. London: Routledge \& Kegan Paul.

Morozov, E. 2013. The price of hypocrisy. Frankfurter Allgemeine Zeitung. http://www.faz. net/aktuell/feuilleton/debatten/ueberwachung/information-consumerism-the-price-ofhypocrisy-12292374.html. Accessed 05 Aug 2013. 